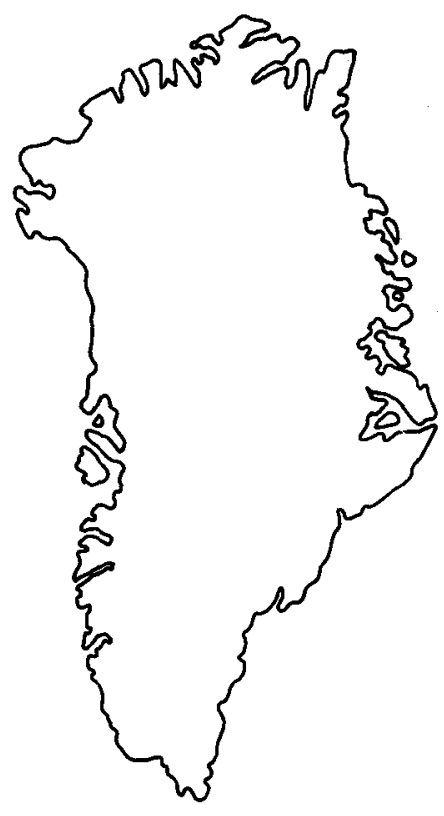

\title{
The crystalline rocks of western and southern Dove Bugt, North-East Greenland
}

\author{
B. Chadwick, C. R. L. Friend and A. K. Higgins
}

The land areas around Dove Bugt are dominated by quartzo-feldspathic orthogneisses with a complex history of emplacement and deformation. The oldest rocks recognised are supracrustal units, mainly marbles and rusty-weathering metasedimentary rocks. Locally gabbro-anorthosite units are associated with the supracrustal rocks. These rock units are cut by different phases of the gneisses, of which the most abundant are grey banded orthogneisses. Two different varieties of pink orthogneiss are also recognised. Different types of tabular amphibolitic bodies, relicts of dykes or sills, cut most rock types.

The area lies within the East Greenland Caledonian fold belt, but available isotopic data suggest that the crystalline rocks include Archaean and early Proterozoic suites which have undergone uncertain degrees of Caledonian reworking. It is not clear at present how much of the deformation history of at least four periods of deformation and associated mylonitisation is Caledonian, and how much pre-Caledonian.

B. C., Department of Geology, University of Exeter, Exeter EX4 4QE, U.K.

C. R. L. F, Department of Geology, Oxford Polytechnic, Oxford OX3 OBP, U.K.

A. K. H., Geological Survey of Greenland, Øster Voldgade 10, DK-1350 Copenhagen

$K$, Denmark.

Daniel Bruun Land, Lindhard $\varnothing$, Rechnitzer Land, Ad. S. Jensen Land and the islands in the western part of Dove Bugt (fig. 1) were mapped during the second year of the North-East Greenland project 1988-90 (Henriksen, 1990). Mapping was carried out on aerial photographs at scales of 1:50 000 or 1:75000, mostly working from camps, but Rechnitzer Land and Ad. S. Jensen Land were seen only on helicopter reconnaissance. The area is composed of a range of high-grade orthogneisses, metasedimentary rocks, amphibolites and metagabbros. The complex structure includes polyphase nappes and belts of mylonite.

The main lithological units are described in approximate chronological sequence, their relative ages having been established, as far as possible, principally on the basis of discordant intrusive relationships. The oldest sequence appears to be the supracrustal rocks. Quantitatively the most important are units of grey and pink quartzo-feldspathic orthogneisses with a complex history of emplacement and deformation. Anorthositic rocks occur locally. Due to the pace of mapping required for completion of the 1:500 000 map sheet (a major aim of the North-East Greenland project), time did not allow resolution of many of the complex problems of structure and genesis.
The studied area lies within the East Greenland Caledonian fold belt. Gneisses at Danmarkshavn (Steiger et al., 1976) and others collected in 1988 in the region immediately to the south have yielded isotopic age data which suggest that the rocks in the western part of Dove Bugt include Archaean and early Proterozoic suites which have undergone uncertain degrees of later Caledonian reworking. Isotopic age dating on samples collected in 1989 is in progress.

\section{Supracrustal rocks}

Supracrustal rocks form thin, but persistent, heterogeneous units within the orthogneisses. Their age is unknown, but in comparison with supracrustal rocks of other areas in Greenland known to the authors they have more in common with Proterozoic associations, for example the Ammassalik area, South-East Greenland (Chadwick et al., 1989), than with Archaean associations. They are most conspicuous in Daniel Bruun Land, Lindhard $\varnothing$ and the semi-nunataks at the head of Bræfjorden. Local broader units of metasedimentary rocks occur in south-east Rechnitzer Land and northeast Ad. S. Jensen Land. Supracrustal rocks show a high degree of modification in contact with the gneisses. 


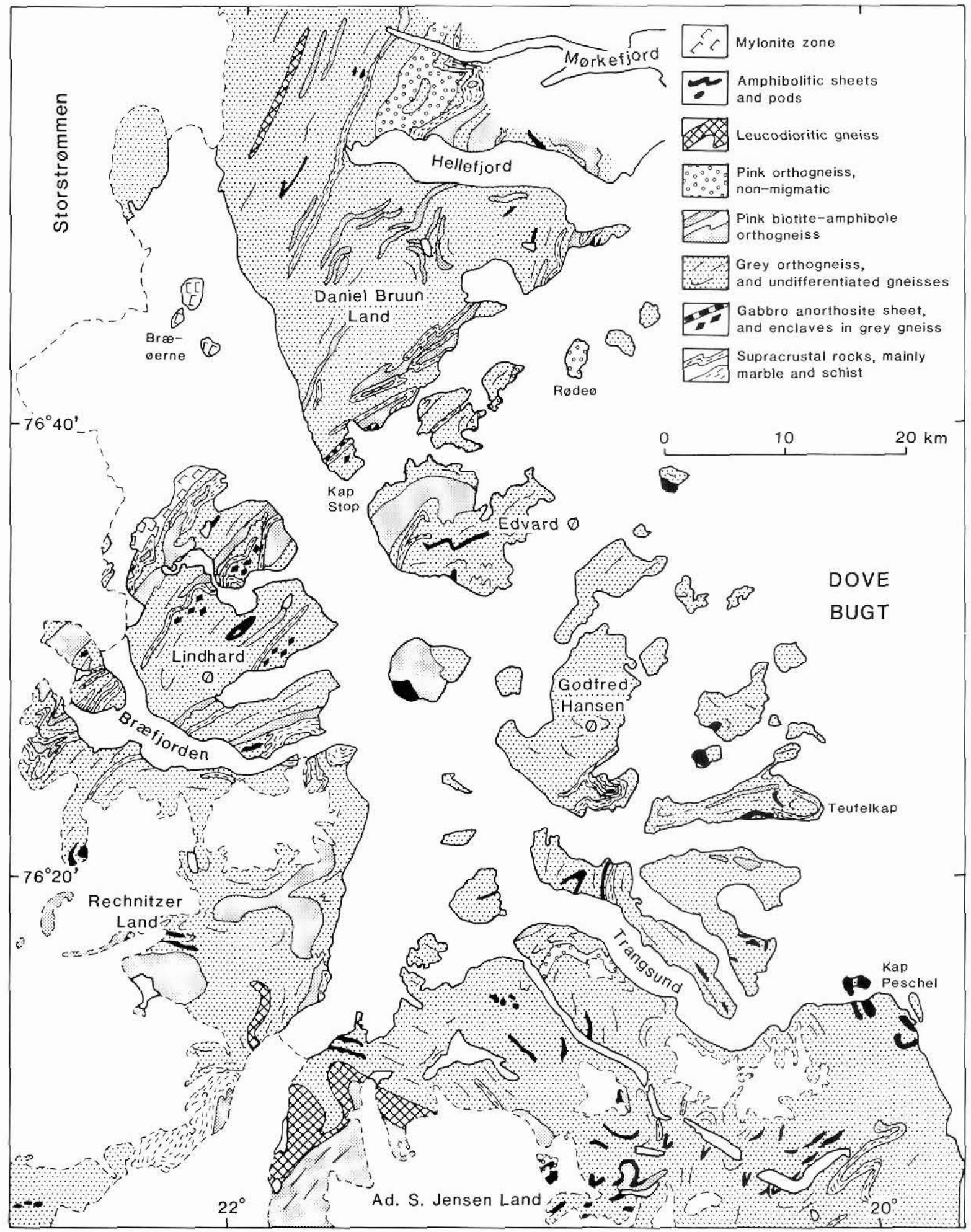

Fig. 1. Geological map of the areas on the western and southern sides of Dove Bugt. 


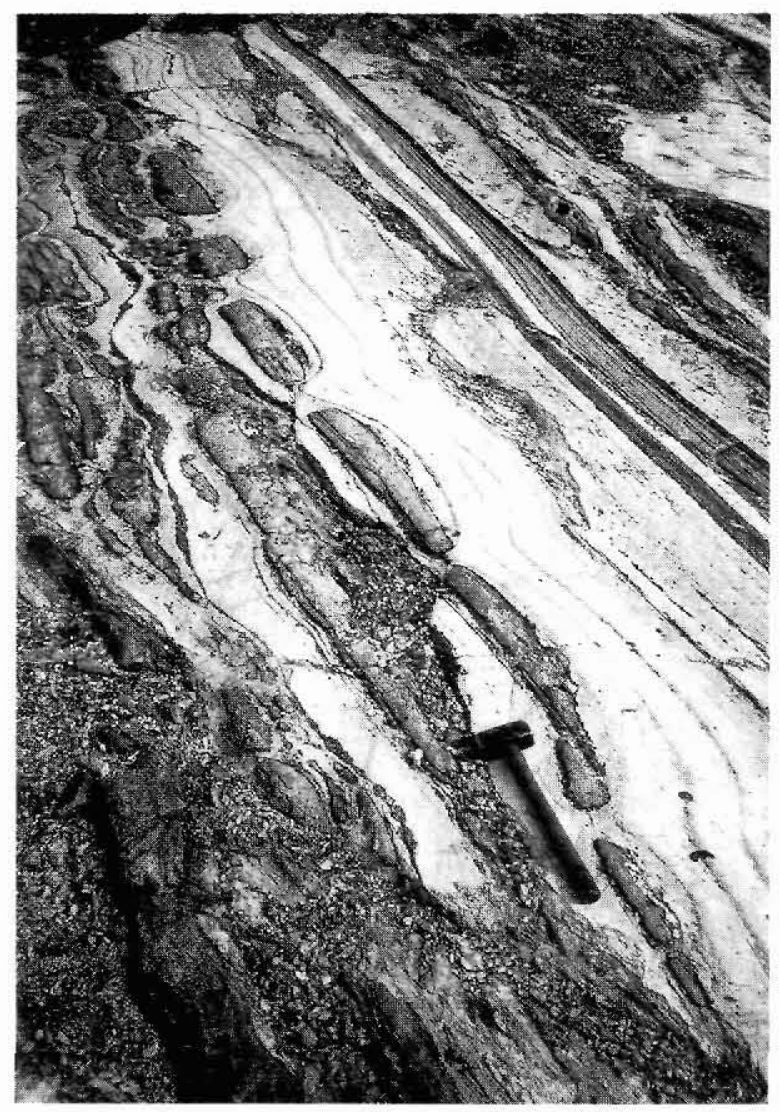

Fig. 2. Banded marble unit showing boundinaged quartzitic layer; near head of Hellefjord.

Whilst most of the gneisses are clearly younger, it is possible that a substantial portion of the grey gneisses may once have formed the basement to the supracrustal rocks.

The most prominent supracrustal rocks are marbles and associated calc-silicate lithologies (fig. 2), which in some areas are important geometrical markers. The marbles are generally coarse-grained with variable amounts of graphite, phlogopite, diopside, olivine, garnet, quartz, grey feldspar, amphibole and pink or green apatite. A $30 \mathrm{~cm}$ sheet of magnetite intergrown with chlorite occurs in marble at one locality adjacent to a sheet of pink granitic gneiss.

Rusty-weathering metasedimentary rocks which are commonly inter-layered with the marbles include quartz-rich schists, micaceous quartzites, garnetiferous schists and gneisses. Sillimanite, cordierite, and disseminated pyrite, chalcopyrite and graphite occur in some of the metasedimentary rocks.

Amphibolites and garnet amphibolites forming concordant layers are commonly associated with the metasedimentary rocks. Gabbroic layering is common in some layers in areas of low strain, supporting the interpretation of an intrusive origin. No evidence for an extrusive origin was found.

\section{Gabbro-anorthosite}

Distinctive units of leucogabbroic and anorthosite rocks occur in southern Daniel Bruun Land, Lindhard $\varnothing$ and the semi-nunataks at the head of Bræfjorden. The main sheet, traced for more than $5 \mathrm{~km}$ in the vicinity of Kap Stop, is up to $120 \mathrm{~m}$ thick, and is bounded on one side by orthogneisses and on the other side by metasedimentary rocks. Internally, it shows heterogeneous deformation with a variably intense foliation. However, relict igneous textures are preserved in areas of low strain. They include cumulus plagioclase laths up to $15 \mathrm{~cm}$ across densely packed in a matrix of dark green amphibole. In some places a few relict cores of bright green clinopyroxene occur within the interstitial amphibole. The leucogabbro sheet is cut by discordant layers of grey and pink orthogneiss and amphibolite dykes. The dykes are deformed and cut the grey gneisses, but their age relative to pink gneisses was not seen.

Away from this main sheet the anorthositic rocks become increasingly broken up and fragmented. They occur as rafts and enclaves contained within a matrix of remobilised anorthosite, grey gneiss and pegmatite (fig. 3). Tracts rich in these enclaves form important geometrical markers.

Similar rocks found in 1988 south-west of Bessel Fjord were compared with Archaean anorthosites of southern West Greenland (Henriksen et al., 1989). However, until some conclusive isotopic data are obtained the precise age relations remain uncertain.

\section{Quartzo-feldspathic orthogneisses}

The area around Dove Bugt is dominated by quartzofeldspathic orthogneisses; in the absence of isotopic data their ages remain unknown. Original contact relationships have in many cases been obscured by high strain and polyphase deformation, such that contacts between different rock units are now generally concordant.

Polyphase grey banded orthogneisses are most abundant. In areas of low strain they comprise a variety of different phases distinguished by varying grain size and slightly different proportions of biotite. In some cases the gneisses are augen textured. Amphibole is a common mineral in some areas, but it commonly appears to be derived from the disaggregation of basic enclaves, and its status as a primary component is thus uncertain. 


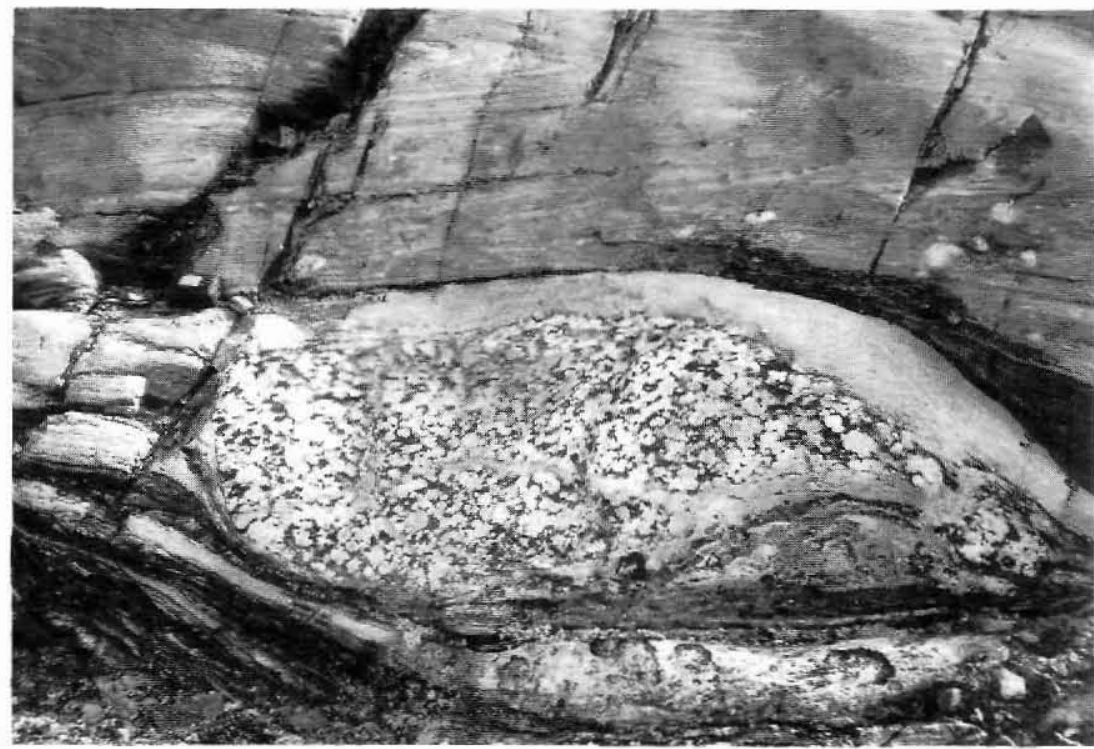

Fig. 3. Enclave of gabbro-anorthosite in grey orthogneiss, northern Lindhard $\varnothing$. Scale shown by camera-case to the left of, and above, the anorthosite lens.

The age relationships within the complex are unclear and it is highly likely that components were added at several times. The contacts with the supracrustal rocks and anorthositic rocks commonly suggest that the grey gneisses are younger, but this age relation may be due to remobilisation of the gneisses. As noted above, it is possible that a portion of the rocks designated here as grey gneisses may once have formed a basement to the supracrustal rocks.

There are two different units of pink gneisses, the age relationships of which were not established. In places, it appears that there is a gradation between them. Both units are folded and are important geometrical markers. One unit comprises pink, medium- to coarse-grained, pegmatite-banded, biotite and/or amphibole gneisses. The pegmatite banding is parallel to the axial surfaces of folds which suggests that this unit may be older than the second group of pink gneisses, which are mediumgrained, foliated, granitic gneisses lacking the effects of significant migmatisation.

Distinct units of leucodioritic gneiss occur in several areas. A body in north-west Daniel Bruun Land extends towards Mørkefjord and comprises $70-80 \%$ felsic minerals with biotite, garnet and amphibole as the mafic phases. Locally discontinuous layers contain extremely large garnets up to $20 \mathrm{~cm}$ in size with symplectite textures associated with clinopyroxene and epidote. Some of these layers may be derived from coarse-grained areas which appear to have a relict gabbroic texture. Other leucodioritic bodies occur in Ad. S. Jensen Land and east Rechnitzer Land. The age relationships are not clear, but they appear to post-date the grey orthogneisses.
Red granitic gneisses appear to be the youngest gneissic units in the region. They are foliated, coarse augen gneisses, with reddish feldspar augen up to $5 \mathrm{~cm}$ long. Major sheets occur in Daniel Bruun Land, north of inner Hellefjord, at Rødeø and south of Trangsund in north-west Ad. S. Jensen Land.

\section{Dykes}

Several different types of tabular amphibolitic bodies with discordant relationships with their host gneisses occur throughout the area; they are found cutting most of the main rock types described above. They vary from sheets a few metres thick to large masses of metadolerite which are presumed to be relicts of tectonically disrupted dykes or sills. No cross-cutting relationships were found, but some degree of chronological distinction can be made on the basis of their metamorphic history.

Tabular 'eclogitic' pods derived from basic dykes occur in a relatively restricted area of Edvard $\varnothing$. They have reddish brown cores of garnet and clinopyroxene and dark green margins showing retrogressive development of an amphibole + plagioclase \pm garnet assemblage. They resemble the 'eclogitic' dykes found in the Ammassalik area of South-East Greenland (Friend \& Nutman, 1989; Nutman \& Friend, 1989), and a similar lithology has also been described from Payer Land in North-East Greenland (Larsen, 1980). The distribution of these finds is too scattered for them to be considered characteristic of an eclogite-bearing province.

The other dykes may be divided into two groups, the first broadly doleritic, the second noritic. Many of the 
thicker metadolerites preserve relict igneous textures in assemblages of amphibole, pyroxene and plagioclase intergrown with fine-grained garnet. In places original igneous mineralogy is overprinted by amphibole pseudomorphs after pyroxene. The noritic group also occurs as a series of disrupted pods and lenses in gneisses. Preserved cores are occupied by relict igneous mineralogies including pyroxene phenocrysts set in a plagioclase matrix. Notable examples occur in south-west Godfred Hansen $\varnothing$, on islands off Kap Peschel, in Ad. S. Jensen Land, and in southern Rechnitzer Land.

The most striking feature of the dykes is their response to deformation, many having undergone considerable extensions. For example, a pod about $80 \mathrm{~m}$ thick may pass into a small neck with one or two pods only about a metre or so in diameter. These pods may be separated by one or two kilometres from the next pod along strike.

\section{Structure and metamorphism}

The structure is complex and the result of superimposed folding and mylonitisation. Much of the foliation and migmatisation in the orthogneisses and supracrustal rocks predates the folding episodes. Most of the deformation appears to have taken place under amphibolite facies conditions. Peak metamorphism reached middle to upper amphibolite facies, but possible relicts of granulite facies in a small area of orthogneisses on Lindhard $\varnothing$ suggest more extreme conditions were reached locally. Indications of static retrogression are shown by the symplectic breakdown of garnet and replacement of sillimanite by muscovite. Chlorite and epidote are common along some of the late shear zones suggesting development under greenschist facies conditions.

Large-scale fold relationships suggest at least four periods of folding, all of which affect the main gneissic banding. The earliest gave rise to isoclines with extremely attentuated fold cores (fig. 4). The early isoclines are folded by younger isoclines with more rounded fold noses. Interference patterns are extremely complex. Around the head of Bræfjorden a nappe-scale sheath fold is outlined by units of supracrustal rocks and pink orthogneisses. The younger isoclines are deformed by major asymmetric folds which appear to verge mainly north-west. The latest folds are gentle upright structures. A strong linear fabric with shallow plunge is coaxial with most folds of all scales associated with the principal isoclinal phases and the major asymmetric phase. It plunges mainly to the south-west or locally to the north-east.

Several generations of mylonitic structures occur within the gneisses and supracrustal rocks. Some are relatively early in the structural sequence because they can be traced around isoclinal folds. Other mylonites are associated with the limbs of some of the isoclines. The most extensive mylonite belt occurs in orthogneisses and supracrustal rocks in a shallow zone up to 5 $\mathrm{km}$ wide crossing west Lindhard $\varnothing$ and the Bræøerne. Intense linear fabrics lie within the foliation in the orthogneisses. Most of the marble in this zone occurs in mélanges with a coarse-grained carbonate matrix containing blocks of mylonitised orthogneiss, paragneiss and aggregates of diopside. Kinematic indicators show that the principal displacement was up from the southwest, parallel to the lineation. The mylonite $S$ fabric is folded by small-scale asymmetric structures coaxial with

Fig. 4. Isocline with attenuated fold core on south side of Teufelkap (Djæuleøen). Cliff is about $900 \mathrm{~m}$ high.

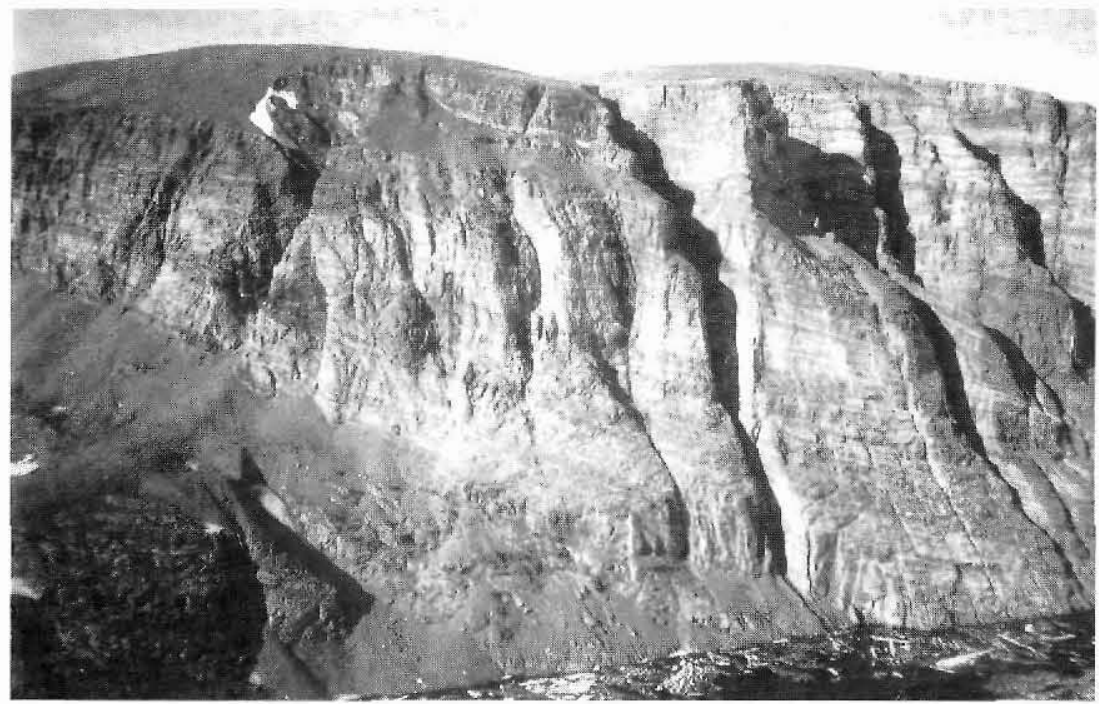


the lineation. The zone as a whole appears to be progressively dropped down to the north-west on NWverging asymmetric folds until it becomes concealed beneath the ice of Storstrømmen.

One particular set of mylonitic structures is noteworthy because it formed in accommodation structures at the boudin necks in the dykes. On Lindhard $\varnothing$ the relationships suggest that some of the dykes cross-cut some of the mylonites.

The age of the deformational episodes cannot be constrained without isotopic data. Hence it is not possible to establish the relationships with the Caledonian deformation in Dronning Louise Land. Moreover, the relation between the structures and the major shear zone that trends NNE through Storstrømmen and separates Dove Bugt from Dronning Louise Land (Friderichsen et al., 1990) remains unknown.

\section{References}

Chadwick, B., Dawes, P. R., Escher, J. C., Friend, C. R. L., Hall, R. P., Kalsbeek, F., Nielsen, T. F. D., Nutman, A. P., Soper, N. J. \& Vasudev, V. N. 1989: The Proterozoic mobile belt in the Ammassalik region, South-East Greenland (Ammassalik mobile belt): an introduction and appraisal. Rapp. Grønlands geol. Unders. 146, 5-12.
Friderichsen, J.D., Holdsworth,R. E., Jepsen, H. F. \& Strachan, R. A. 1990: Preliminary report on the geology of Dronning Louise Land, North-East Greenland. Rapp. Grønlands geol. Unders. 148 (this volume).

Friend, C. R. L. \& Nutman, A. P. 1989: The geology and structural setting of the Proterozoic Ammassalik Intrusive Complex, East Greenland. Rapp. Grønlands geol. Unders. 146, 41-45.

Henriksen, N. 1990: Regional geology and 1:500 000 mapping in North-East Greenland. Rapp. Grønlands geol. Unders. 148 (this volume).

Henriksen, N., Friderichsen, J. D., Strachan, R. A., Soper, N. J. \& Higgins, A. K. 1989: Caledonian and pre-Caledonian geology of the region between Grandjean Fjord and Bessel Fjord $\left(75^{\circ}-76^{\circ} \mathrm{N}\right)$, North-East Greenland. Rapp. Grønlands geol. Unders. 145, 90-97.

Larsen, H. C. 1980: A high-pressure granulite facies complex in north-west Payers Land, East Greenland fold belt. Bull. geol. Soc. Denmark 29, 161-174.

Nutman, A. P. \& Friend, C. R. L. 1989: Reconnaissance P,T studies of Proterozoic crustal evolution of the Ammassalik area, East Greenland. Rapp. Grønlands geol. Unders. 146, 48-53.

Steiger, R. H., Harnik-Šoptrajanova, G., Zimmermann, E. \& Henriksen, N. 1976: Isotopic age and metamorphic history of the banded gneiss at Danmarkshavn, East Greenland. Contrib. mineral. Petrol. 57, 1-24. 